\title{
Dystopian Cybernetic Environment in Kurt Vonnegut's Slaughterhouse-Five
}

\author{
Ruzbeh Babaee \\ Faculty of Modern Languages and Communication, University Putra Malaysia, Malaysia \\ Wan Roselezam Bt Wan Yahya \\ Faculty of Modern Languages and Communication, University Putra Malaysia, Malaysia \\ Shivani Sivagurunathan \\ Nottingham University, Malaysia Campus, Malaysia
}

\begin{abstract}
Cybernetics is particularly well-suited to cultural history since it resonated with an American cultural mood that included World War II anxieties and worries that communism indicated that human beings could degenerate into unthinking, perfectly intelligent machines. Kurt Vonnegut's Slaughterhouse-Five (1969) illustrates people who become enslaved to a controlling system of cybernetics that carries out its power through time and war. In this study, I examine Slaughterhouse-Five in which the cybernetic system creates a dystopian society and reduces human beings into obedient robots. Vonnegut's Slaughterhouse-Five demonstrates that cybernetics as a metaphor for control of the mind leaves no space for individuals to decide for their own lives. This analysis investigates the ways through which cybernetics manipulates human beings in Vonnegut's Slaughterhouse-Five.
\end{abstract}

Index Terms - cybernetics, dystopia, war, time, machine, mind control

\section{INTRODUCTION}

Slaughterhouse-Five (1969) recounts Kurt Vonnegut's personal experience at the bombing of Dresden in February 1945, when thousands of bombs were dropped on the city, and caused a tragedy more devastative than the atomic bomb at Hiroshima. Vonnegut "recalls that he considered writing what he had seen soon after it [war] was over" (Tomedi, 2004, p. 56). Harold Bloom asks, "Indeed, what can one say about the madness in our time of human beings slaughtering their fellow human beings - coldly, methodically, scientifically, in numbers heretofore inconceivable?" (2009, p. 5). Slaughterhouse-Five narrates Billy Pilgrim's war experience, especially at Dresden, and his traveling through time as well as his kidnapping by the inhabitants of the planet Tralfamadore that is "an equally dubious utopia in which he [Billy] secludes himself' (Simmons, 2009, p. 175).

Vonnegut's Slaughterhouse-Five is a dystopian fiction in which the border between not only real and fiction, but also human and machine is blurred for the presentation of a more tragic picture of World War II. Robert Tally (2011) states that "The humane fatalism of Slaughterhouse-Five suggests one way of looking at the disjointed, often painful, experience of social life in the United States in the twentieth century (2011, p. 85).

The novel begins, "All this happened, more or less" (Slaughterhouse-Five 1). The phrase "more or less" negates the accuracy of the claim that "all this happened." But Vonnegut immediately says, "The war parts, anyway, are pretty much true." Slaughterhouse-Five is a criticism of war in a cybernetic environment that, according to Paul N. Edwards (1996), is a "closed-world discourse" in which "containment, with its image of an enclosed space surrounded and sealed by American power, was the central metaphor" (1996, p. 8). Cybernetics considers ideas of control and communication. It investigates the feedback processes in self-regulating systems such as machines, animals, and the communication with their environment. The spatiality of these systems considers not only physical locations, but also social spaces and relationships. According to David Porush (1985) in The Soft Machine:

[Vonnegut] does not manipulate the very act of fictional communication itself, nor explore language, as tacit ways of eluding the control over communication proposed by cybernetics until his later novel Slaughterhouse Five (1969), where he experiments with the structure of novelistic presentation. (1985, p. 86)

Slaughterhouse-Five is an illustration of the American cybernetic environment that surrounds, affects and links all living and dead matters in the world by ways of interaction. In Slaughterhouse-Five, Vonnegut uses war context to convey cybernetic war communication that motivates young people to war and massacre.

In addition to war, Slaughterhouse-Five introduces time as another controlling factor. For Vonnegut time is different from the physical linear time. According to Christina Jarvis (2009), Vonnegut employs "the vehicle of time travel and a fractured narrative that juxtaposes the firebombing of Dresden" (2009, p. 65). Vonnegut depicts Billy, the protagonist of the novel, like a machine that can move mentally to past, present, and future. Billy finds "himself with a time sense that changes the boundaries of spatial perception for the whole species" (Haraway, 1991, p. 179). 
Vonnegut's dark picture criticizes our contemporary world and the devastative direction in which we are headed. Slaughterhouse-Five is a criticism of cybernetics that reduce human to intelligent machine. Lawrence R. Broer explains that in Slaughterhouse-Five "we encounter the mindless hating and killing, superpatriot machines of Howard Campbell, Colonel Wild Bob, and Bertram Copeland Rumfoord, whose glorifications of war and exhortations to battle appear ludicrous alongside the pitiful suffering of Billy and his comrades" (2009, p. 51). Egotism, sentimentality, materialism, and blind patriotism are the new American values (Giannone, 1977, p. 87) in a cybernetic environment in which time becomes a myth and "we are all chimeras, theorized and fabricated hybrids of machine and organism" (Haraway, 1991, p. 150).

In this study, I examine Slaughterhouse-Five in which the cybernetic system creates a dystopian society and reduces human beings into obedient robots. Vonnegut's Slaughterhouse-Five demonstrates that cybernetics as a metaphor for control of the mind leaves no space for individuals to decide for their own lives. The present study explores war and time as two controlling cybernetic factors that degenerate human being into unthinking, intelligent machines in Vonnegut's Slaughterhouse-Five.

\section{CyBernetic WAR MACHINE}

While Vonnegut was looking for a muse, he found himself in the house of an old war friend, Bernard V. O'Hare. As these two old friends of war begin to review their war memories, Vonnegut notices that his presence makes Bernard's wife, Mary, upset. He testifies that he does not know why Mary dislikes him as he has never done anything, to his knowledge, to disturb her and her husband. Ironically it is Mary who serves as Vonnegut's muse, and the novel is dedicated to her. Mary shows her fury and says:

"Well, I know," she said. "You'll pretend you were men instead of babies, and you'll be played in the movies by Frank Sinatra and John Wayne or some of those other glamorous, war-loving, dirty old men. And war will look just wonderful, so we'll have a lot more of them. And they'll be fought by babies like the babies upstairs," referring to hers and Vonnegut's children (Slaughterhouse-Five, P. 7).

In fact, Bernard's wife accuses Vonnegut of composing a fiction that glorifies the war. Vonnegut understands that she is worried for her children who might be sacrificed by the war. Then he promises her to entitle his novel The Children's Crusade: A Duty Dance with Death. Bernard's wife scares that war affects her children's mind and encourages them to massacre. It is exactly what cybernetics does. Through the novel, Vonnegut attempts to consider a historical issue in American public discourse: the ruin of Dresden through killing machines.

Vonnegut shows war as a manifestation of feedback loops that, according to American mathematician, David Tomas (2000), "govern present and future actions according to a past set of meanings" (2000, P. 28). In Slaughterhouse-Five, war is a governing system based on past experience. Due to such terrifying experience, people like Mary scare that war can be a governing system for their children in future.

Slaughterhouse Five displays a statement based on the relationship between writer and writing regarding a feedback loop system that considers how human perceives his/her environment and how he/she reacts to it. Norbert Wiener observed that what marks cybernetics as a new discipline is that it focuses not on the inner essence of things but on the systems of feedback and communication regulating the behavior of any entity: organic, human, or mechanical. War is the system that regulates the behaviors of the people in Slaughterhouse-Five. Wiener, in his work entitled Cybernetics: or Control and Communication in the Animal and the Machine, compares human to machine to show how human communication is similar to the way machine functions when given an order to complete a duty. Similarly when humans send messages, they become just aware that the messages have been received when the recipients reply, verbally or nonverbally. Also, Wiener offers that humans function in a machine-like behavior that is quite based on information processing and the desire to control human environment. By his article, Cybernetics In History, Wiener (1988) extends his discussion and explains:

society can only be understood through a study of the messages and communication facilities which belong to it; and that in the future development of these messages and communication facilities, messages between man and machines, between machines and man, and between machine and machine, are destined to play an ever increasing part. (1988, p. 15)

Since the emergence of Wiener's notions, controlling systems have turned to be an important part of our society. Vonnegut's concern in Slaughterhouse-Five is about war as a controlling system that communicates its values and expects all of its orders to be accepted by the machine-like human. In Slaughterhouse-Five, cybernetics transforms people to "fully automated boobs, ready to conform to the most convenient mold, whether in the mistaken interests of survival or friendliness or out of the lack of imagination to do anything better; thus, they become the ready slaves of whatever anonymous bureaucracies, computers, or authoritarian institutions take hold of their minds. (Broer, 2009, p. 52). Vonnegut sees that war turns individuals into machines and leaves them with no power to decide for their destiny.

As David Porush (1985) argues, cybernetics is "to embrace not only the information sciences but a metaphor so deeply engrained in our culture, so silently driven down to the roots of our imaginations, that it achieves the status of an element in a new mythology" $(1985$, p. 2) that individuals, and the cultural products of their thoughts, like literature, can be explained in terms of machines, and that intelligence can correspondingly be reproduced by artificial programs. Vonnegut also shows the metaphor of the machine comes into play. As Charlie Chaplin mentions, "machine men, with 
machine minds, and machine hearts" comes true; then Vonnegut's Slaughterhouse-Five is a criticism of the cybernetic war machine that manipulates humans' mind. Vonnegut shows the ways that war machine provokes humans' patriotic feelings to sacrifice the children of a nation. Thus, the novel becomes a warning against the war as a system of control and persuation. As Paul Edward (1996) describes the war machine procedures of the era,

[as] metaphors, such systems constituted a dome of global technological oversight, a closed world, within which every event was interpreted as part of a titanic struggle between the superpowers. (1996, p. 1)

Vonnegut criticizes this system of the war machine in which human is trapped. Slaughterhouse-Five is an antiwar fiction, but it asserts that war is an unavoidable mistake that humans are bound to repeat. Vonnegut links all modern war to the Children's Crusade of 1213. As the narrator of the novel says:

the Children's Crusade started in 1213, when two monks got the idea of raising armies of children in Germany and France, and selling them in North Africa as slaves. Thirty thousand children volunteered, thinking they were going to Palestine. (Slaughterhouse-Five, p. 8)

Vonnegut believes that war deceives young people since they cannot understand the reality. (Schatt, 1976, P. 82). He says: "We had been foolish virgins in the war, right at the end of childhood" (Slaughterhouse-Five, P. 7). Billy Pilgrim is a man who is deceived by the war machine. Billy Pilgrim is a man who is deceived by the war machine. He becomes the innocent pilgrim in a cruel and absurd world which controls its people through war. When Billy sees the Americans cleaned and shaved, he is shocked and understands how young they are, and says: "My God, it's the Children's Crusade!" (Slaughterhouse-Five 46). Vonnegut attempts to illustrate war as a controlling system that manipulates people's mind.

Even in Tralfamadoria, Billy expects "the Tralfamadorians to be baffled and alarmed by all the wars and other forms of murder on Earth. He expected them to fear that the Earthling combination of ferocity and spectacular weaponry might eventually destroy part or maybe all of the innocent Universe" (Slaughterhouse-Five, p. 50). When Tralfamadorians kidnap Billy Pilgrim, they place him in a zoo with Montana Wildhack, a Hollywood porn star. There someone asked Billy "what the most valuable thing he had learned on Tralfamadore was so far, and Billy replied, "How the inhabitants of a whole planet can live in peace as you know, I am from a planet that has been engaged in senseless slaughter since the beginning of time" (Slaughterhouse-Five, p. 51). Vonnegut shows Billy's historical concern about slaughter and humiliation. Billy says:

I myself have seen the bodies of schoolgirls who were boiled alive in a water tower by my own countrymen, who were proud of fighting pure evil at the time. '... 'And I have lit my way in a prison at night with candles from the fat of human beings who were butchered by the brothers and fathers of those school girls who were boiled. Earthlings must be the terrors of the Universe! If other planets aren't now in danger from Earth, they soon will be. So tell me the secret so I can take it back to Earth and save us all: How can a planet live at peace?' (ibid).

Billy asks a Tralfamadorian "'How-how does the Universe end?"”

He answers, "“we blow it up, experimenting with new fuels for our flying saucers. A Tralfamadorian test pilot presses a starter button, and the whole Universe disappears."

"If you know this, said Billy, 'isn't there some way you can prevent it? Can't you keep the pilot from pressing the button?",

"'He has always pressed it, and he always will. We always let him and we always will let him. The moment is structured that way."”

“"So,' said Billy gropingly, I suppose that the idea of, preventing war on Earth is stupid, too.'” (ibid)

Billy sees that the idea of war is unavoidable. In fact, it is cybernetics that encourages people to kill each other by pressing a button. Peter Galison (1999) calls cybernetics a "Manichean science" (Hayles, 1999, p. 106). As Katharine Hayles explains:

In a fine-grained analysis of Wiener's collaboration with Julian Bigelow to develop an antiaircraft (AA) weapon during World War II, Galison brilliantly shows that Wiener's construction of "the enemy" was significantly different from that portrayed in war propaganda or even in other technical reports. Rather than seeing the enemy in conventionally human (or, in the case of propaganda, subhuman) terms, Wiener modeled the enemy-for example, a fighter pilot trying to evade AA fire-as a probabilistic system that could effectively be countered using cybernetic modeling. (1999, p. 106)

Vonnegut depicts this cybernetic modeling through a story within Slaughterhouse-Five. He says about Trout's book entitled The Gutless Wonder that is about a robot, who dropped jellied gasoline on human beings. It was dropped on them from airplanes. Robots did the dropping. They had no conscience, and no circuits which would allow them to imagine what was happening to the people on the ground (Slaughterhouse-Five, p.72). The robot is a metaphor of a human who becomes an intelligent machine in war time. Vonnegut continues that "robot looked like a human being" and later "was welcomed to the human race" (ibid). Trout's robot is like Wiener's imagined firing machine that

could evolve new rules based on prior observation-that is, it could learn. Thus the firing system would evolve to become as Manichean as the enemy it faced. Galison argues that this strategy enabled a series of substitutions and identifications that mapped the enemy pilot onto the servo-controller and ultimately onto the allied war personnel behind the servo-controller" (Hayles, 1999, p. 106) 
In cybernetics, pilot acts like a servo-mechanism. Thus, according to Hayles, "through this relay system, the enemy becomes like us and we become like the enemy: enemy mine... The cybernetic machine (and, byex- tension, cybernetics itself)" becomes engaged in "a bloody struggle in which Manichean tactics were used by both sides to kill as many humans as possible" (Hayles, 1999, p. 107). Cybernetic machine turns human beings into killing machines, as eventually "Billy Pilgrim was armed as he snoozed. His companions had insisted that he arm himself, since God only knew what sorts of killers might be in burrows.... who would never quit killing until they themselves were killed" (Slaughterhouse-Five 85). Vonnegut demonstrates that the function of cybernetic war is to persuade people not to leave killing until they themselves are killed. As Todd Davis (2006) notes, "For Vonnegut then, Dresden represents his complete disillusionment with the grand narratives of American culture, especially the narrative of scientific progress in which Vonnegut had innocently placed his trust. After witnessing the awesome power of science in the service of humanity's hatred, Vonnegut essentially lost faith.” (2006, p. 76). Thus, through Slaughterhouse-Five, Vonnegut attempts to share his feelings towards scientific progress with his readers and make them aware of the controlling power of science.

\section{Cybernetic Time Machine}

Slaughterhouse-Five introduces a new mode of time that deconstructs the traditional notion of time. As Harold Bloom (2009) observes, "More than a conventional reminiscence of war, Slaughterhouse-Five is an attempt to describe a new mode of perception that radically alters traditional conceptions of time and morality" (2009, p. 5)

Vonnegut's most noticeable narrative technique considering time and space is related to the Tralfamadorian view of time. As Vonnegut at the title page of the novel says: "This is a novel somewhat in the telegraphic schizophrenic manner of tales of the planet Tralfamadore, where the flying saucers come from." For the Tralfamadorians "all moments, past, present, and future, always have existed, always will exist" (Slaughterhouse-Five, p. 12).

On the planet of Tralfamadore, time is considered not as a river, but as a range of mountain. This spatial metaphor defines time in relation to space and shows that all moments are present at once. As Billy Pilgrim describes:

All moments, past, present, and future, always have existed, always will exist. The Tralfamadorians can look at all the different moments just the way we can look at a stretch of the Rocky Mountains, for instance. They can see how permanent all the moments are, and they can look at any moment that interests them. It is just an illusion we have here on Earth that one moment follows another one, like beads on a string, and that once a moment is gone it is gone forever (Slaughterhouse-Five, p. 12).

This shows that the novel has a non-linear plot in which Billy Pilgrim jumps here and there and experiences wartime. According to David Simmons, in The Anti-Hero in the American Novel, Tralfamadorians "have the capacity to view any moment in time whenever they choose" (2008, p. 121). Actually, considering history as a consistent present tense, or as a spatial phenomenon in which all tenses can be present, is similar to "Henri Bergson's theory of memory in which all moments coexist in more or less concentrated forms. Memories closer to the present consciousness seem more concrete, concentrated into easily recognizable images; more distant memories are more disparate, fuzzier we might say" (Tally, 2011, p. 13). Thus, space and time are commingled distant memory. "All memories are in fact present at once; they are just dispersed over a landscape that spreads out before the consciousness" and "time is essentially space" (ibid). Billy Pilgrim becomes memory to be free to travel in time and space. Billy who is "unstuck in time" becomes an immortal disk that can fly through time and space and display his memories for the reader. As the narrator says:

Billy has gone to sleep a senile widower and awakened on his wedding day. He has walked through a door in 1955 and come out another one in 1941. He has gone back through that door to find himself in 1963. He has seen his birth and death many times, he says, and pays random visits to all the events in between. (Slaughterhouse-Five, p. 10)

Billy Pilgrim breaks the chronology of the story to retell different overlapping scenes. But he only finds repetition. It is a feedback loop of history that is not able to establish a learning process and is doomed to endlessly recur itself. Considering the epigraph of the novel, this recurring seems to be bitter: "The cattle are lowing, / The Baby awakes. / But the little Lord Jesus / No crying He makes." Billy has no control over his life. For instance, one moment he might be a prisoner of WWII and another moment he could be back in his childhood in Ilium, New York in 1922. As the narrator notes:

Billy is spastic in time, has no control over where he is going next, and the trips aren't necessarily fun. He is in a constant state of stage fright, he says, because he never knows what part of his life he is going to have to act in next. (Slaughterhouse-Five, p. 10)

Billy adopts a nonlinear time as a defense mechanism to rationalize his terrible war experience. Through flying in time and space he detaches himself the material world and gets into a virtual world far away from the reality he witnessed in Dresden. By Tralfamadoria, Vonnegut represents a world of information existing parallel to the real world. Becoming a time machine or a disk of information makes Billy able to develop virtual technology through which he can step into a world far away from the real world.

In Slaughterhouse-Five, Vonnegut, as a war survivor, asks the question "Why me?" In fact, he is tortured by this question and through Billy, he attempts to reduce the guilt feeling which one has when one is accidently survived from death, while one's friends and family are perished. For Billy, his survival is not blessing; but instead it is a curse. That is why Billy invents an imaginary world where he can find a justification, where he becomes unstuck in time. Through 
this nonlinear time, life and death become insignificant for him and feeling of guilt disappears from his heart. The Traflamadorians do not live in a three dimensional world. They are not trapped in time to which earthlings are forced to live in. They are able to consider the pleasant moments of their life and ignore the aspects of time they do not like. Therefore, the tragedy of Dresden is insignificant in the vast space time continuum. Also, in the Tralfamadoria death is only a tiny part of existence that is ignored like the bombing of Dresden. Billy finds The Tralfamadorians real since without them he is not able to live. In fact, Tralfamadoria is an unreal world that Billy makes it real to escape from the misery of the real world. Tralfamdorians believe guilt does not exist since people are not responsible for their actions. They believe everything is predetermined and we cannot change the course of events. A Tralfamadorian tells Billy:

Today we do (have peace). On other days we have wars as horrible as any you've ever seen or read about. There isn't anything we can do about them, so we simply don't look at them. We ignore them. We spend eternity looking at pleasant moments (Slaughterhouse-Five, p. 51).

By adopting the Tralfamadorian view, Billy makes himself free from the guilt which one feels when one is locked in time and feels responsible for one's actions. Billy accepts the Tralfamadorian philosophy and believes the Tralfamadorian universe exists since it eliminates the question: "Why me?" Through the Tralfamadorian perspective Billy has no feeling of guilt for being saved since that is how it was and always will happen. He does not feel guilty since there is no reason to and there is nothing that can be done about war. Billy is affected by the Tralfamadorians who believe that the world will finally end because of their experiment with new fuel for their flying saucer. But instead of practicing free will and asking for change, they view the moment as "structured" (Slaughterhouse-Five, p. 37).

In Art of the Motor, Paul Vilirio argues, in "cybernetic space-time" information is valuable when if it is represented fast. Thus, in such an environment, Billy, who "is multiple places in time at once" (Tally, 2011, p. 14), is able to give the reader information about different scenes, events, and places. Vilirio (1995) observes cybernetic space -time as:

one formerly steered a motor vehicle: this is indeed the great aesthetic mutation of INFORMATION technologies. To transfer to the immediate environment the control that until now was exercised over the "object," the engine of displacement--and this, thanks to acquiring a "fractal" dimension, not of space now, but of time, of real time, allowing an individual's proximity to be virtualized with the aid of a process that controls their movements: this is indeed the most astounding use of interactivity. (1995, p. 146)

Escaping from earthly time, Billy is trapped by the cybernetic time that controls every action of him. He has no way to escape from the cybernetic time-space and is just able to travel within it. A Tralfamadorian says to Billy about the essence of time:

Earthlings are the great explainers, explaining why this event is structured as it is, telling how other events may be achieved or avoided. I am a Tralfamadorian, seeing all time as you might see a stretch of the Rocky Mountains. All time is all time. It does not change. It does not lend itself to warnings or explanations. It simply is. Take it moment by moment, and you will find that we are all, as I 've said before, bugs in amber . . . Only on Earth is there any talk of free will (Slaughterhouse-Five, p. 37).

If time is observed as a linear system, then it can convey meaning. But Tralfamadorians are fatalist because time makes no meaning for them. For Tralfamadorians time is predetermined and unchangeable and this is the lesson that Billy learns from them.

Tralfamadorian fatalism makes Billy feels indifferent toward events. Billy's belief in Tralfamadorian philosophy makes him free from taking any responsibility for his own actions. Billy holds Tralfamadorian idea of time since it sets him free from taking any affairs to change the way things are. Trapped in an artificial universe of imperative signals, Billy is not able to escape a controlling environment that dogs his every step. In fact, Billy has lost his own self as a human and defines himself with Tralfamadorian. He thinks that if all human beings see the world as do the Tralfamadorians, then they would not be in suffering anymore. The trick is to only consider the good times and discard the bad, as Billy does and says repeatedly "So it goes".

Vonnegut shows time as a system of homeostasis that forces human systematically resists change. Homeostasis traditionally is

the ability of living organisms to maintain steady states when they are buffeted by fickle environments. When the temperature soars, sweat pours out of the human body so that its internal temperature can remain relatively stable (Hayles, 1999, p. 8).

In the novel, nonlinear time forces Billy to accept everything unquestionably as a part of his destiny. In fact, Billy accepts war and destruction, and massacre as parts of his life. Those people who cannot adopt homeostasis will be eliminated. In other words, cybernetics attempts to eliminate not only the weak, but also the essence of free will in human being. This is only a metaphor for the delicate enslavement of the human to intelligent machine. Thus, in a sense, Billy has to adopt such a meaning of time to avoid of his elimination.

Furthermore, for Billy, homeostasis occurs mentally instead of physically. It means that being unstuck in time, Billy psychologically regulates his inner environment to ensure his stability in response to his experience in the outside environment. Hiding in a slaughterhouse, Billy sees the bombs falling on Dresden by the military flight apparatuses that carry a body within themselves. The Tralfamadorian illusions act as an outlet through which Billy can tell about his war experiences. 
The novel represents a neurotic preoccupation with the concept of time, as the narrator in the first chapter asks himself: "I asked myself about the present: how wide it was, how deep it was, how much was mine to keep" (Slaughterhouse-Five, p. 8). Then he explains how "the time would not pass. Somebody was playing with the clocks, and only with the electric clocks, but with the wind-up kind, too. The second hand on my watch would twitch once, and a year would pass, and then it would twitch again" (Slaughterhouse-Five, p. 9). Here the narrator first presents physical time through clocks, and then psychological time that its passage is unlike physical time. Also while reading Céline and His Vision, a fiction by Erika Ostrovsky, Billy finds out how the main character is similar to him and tends to prevent the rushing movements of a crowd by freezing them. Billy, a flying machine, is controlled by time. In fact, time is both homeostasis and controlling. Billy talks about his being unstuck in time as an impact of having nearly died in a plane crash in 1967. His daughter asks him: "Why is it you never mentioned any of this before the airplane crash?" (Slaughterhouse-Five, p. 13). Later, after visiting his aging mother in the hospital, the narrator contextualizes the event, describing how "this was before Billy had his head broken in an airplane crash... before he became so vocal about flying saucers and traveling in time" (Slaughterhouse-Five, p. 19). Through the text narrator attempts to create meaningful relationship between time travelling and flight apparatus that is responsible for both bombing Dresden and Billy's illusion of time travelling.

Tralfamadorians believe people on earth are not two-legged, but "with babies legs at one end and old people's legs at the other" (Slaughterhouse-Five, p. 38). Thus, in a system that is regulated and controlled by homeostasis and time, change is an illusion, and humans would need just "seeing" only one moment after another, "like beads on a string". For Billy the "true nature of time" is a defense mechanism rationalizing his horrifying experiences in the war. If "all time is all time," then Billy's typical phrase "so it goes" is comprehensible. Because there is no change, free will does not exist, as the narrator says at the end of the novel, "if I am going to spend eternity visiting this moment and that, I'm grateful that so many of those moments are nice" (Slaughterhouse-Five, p. 91)

Consequently, Billy's fatalistic attitude leads him to be seen as subhuman, "a broken kite" of a human, and finally results in the destruction of his world. Vees-Gulani traces the root of Billy's mental disorder, as he explains: "Being 'spastic in time' thus is a metaphor for Billy's repeatedly re-experiencing the traumatic events he went through in the war, particularly during the Dresden bombings". Due to Billy's continual re-experiencing and reminding of the war, Vees-Gulani (2003) explains that "Billy experiences posttraumatic mental issues" (2003, p. 176) and becomes a more unconventional coping mechanism.

\section{CONCLUSION}

Vonnegut's Slaughterhouse-Five considers the paranoid fear of cybernetic system that is responsible for dystopia in which humanity is devaluated. Vonnegut's antiwar fiction illustrates war machine and time machine that produce thoughtless machine-like humans. Vonnegut reveals a sort of submission to the system and demonstrates that human is doomed to slavery by machine. He shows that such the controlling system is always omnipresent, but human must be conscious not be trapped by it. Consequently, by writing against controlling systems of war and time, Vonnegut leaves the readers in a condition to speculate and ask for change. A word may ask for change, but it requires someone to run it.

\section{REFERENCES}

[1] Bloom, Harold. (2009). Kurt Vonnegut's Slaughterhouse-Five. InfoBase Publishing.

[2] Broer, Lawrence R. (2009). “Slaughterhouse-Five: Pilgrim's Progress.” Bloom's Kurt Vonnegut's Slaughterhouse-Five. InfoBase Publishing.

[3] Chaplin, Charlie. (1940). “Chapter 20," Der große Diktator, directed by Charlie Chaplin. Burbank, CA: Warner Home Video, 2007. DVD.

[4] Davis, Todd. (2006). Kurt Vonnegut's Crusade Or, How a Postmodern Harlequin Preached a New Kind of Humanism. State University of New York Press

[5] Edwards, Paul N. (1996). The Closed World: Computers and the Politics of Discourse in Cold War America. Cambridge, MA: The MIT Press

[6] Giannone, Richard. (1977). Vonnegut. Port Washington: Kennikat Press

[7] Haraway, Donna. (1991). "The Cyborg Manifesto," in Simians, Cyborgs, and Women: The Reinvention of Nature. New York: Routledge.

[8] Hayles, N. Katherine. (1999). How We Became Posthuman: Virtual Bodies in Cybernetics, Literature, and Informatics. Chicago: University of Chicago Press

[9] Jarvis, Christina. (2009). "The Vietnamization of World War II in Slaughterhouse-Five and Gravity's Rainbow. "Bloom's Kurt Vonnegut's Slaughterhouse-Five. InfoBase Publishing.

[10] Porush, David. (1985). The Soft Machine: Cybernetic Fiction. New York: Methuen

[11] Schatt, Stanley. (1976). Kurt Vonnegut,Jr. Boston: G.K. Hall

[12] Simmons, David. (2009). New critical essays on Kurt Vonnegut. Palgrave Macmillan

[13] Simmons, David. (2008). The Anti-Hero in the American Novel. Palgrave Macmillan

[14] Tally, Robert T. (2011). Vonnegut and the Great American Novel: A Postmodern Iconography. Continuum International Publishing Group. 
[15] Tomas, David. (2000). "Feedback and Cybernetics: Reimagining the Body in the Age of Cybernetics." In Cyberspace/Cyberbodies/Cyberpunk: Cultures of Technological Embodiment. Burrows, Roger and Mike Featherstone (ed.). London: Sage.

[16] Tomedi, John. (2004). The Great Writers: Kurt Vonnegut. Chelsea House Publishers.

[17] Vees-Gulani, Susanne. (2003). "Diagnosing Billy Pilgrim: A Psychiatric Approach to Kurt Vonnegut's Slaughterhouse-Five." Critique 44.2

[18] Virilio, Paul. (1995). The Art of Motor. Minneapolis: University of Minnesapolis Press.

[19] Vonnegut, Kurt. (1969). Slaughterhouse-Five. Panther Books Ltd 1975.

[20] Wiener, Norbert. [1948] (1965). Cybernetics: or Control and Communication in the Animal and the Machine. 2nd Edition, Cambridge, MA: The MIT Press

[21] Wiener, Norbert. [1950] (1988). The Human Use of Human Beings: Cybernetics and Society. Cambridge, MA: Da Capo Press.

Ruzbeh Babaee is Ph.D. candidate o English literature at the Faculty of Modern Languages and Communication, Universiti Putra Malaysia. His areas of interest are on postmodern fiction, dystopian fiction, and media and cultural studies.

Wan Roselezam Bt Wan Yahya is Associate Professor of English literature at the Faculty of Modern Languages and Communication, Universiti Putra Malaysia. Her research interest ranges from Post-modern, Post-colonial, and Contemporary World Literatures in English.

Shivani Sivagurunathan is a Malaysian writer who lectures at Nottingham University, Malaysia Campus. Her creative work has been published in numerous international magazines and journals. 